\author{
Магденко С.O. \\ асистент \\ кафедра економіки промисловості \\ Одеська національна академія харчових технологій \\ вул. Канатна, 112, г. Одеса, Україна, 65039 \\ E-mail:maglana@meta.ua
}

\title{
ВНУТРІШНІЙ КОНТРОЛЬ ЕФЕКТИВНОСТІ ПРАЦІ НА ПІДПРИЄМСТВАХ ХАРЧОВОЇ ПРОМИСЛОВОСТІ
}

У статті досліджено сутність ефективності праці як складової ефективності виробництва, а також шляхи ії підвищення. Для досягнення мети підприємством необхідно, з одного боку, створювати та застосовувати мотиваційний механізм для кожного працівника, а з іншого боку, застосовувати ретельний контроль ефективності праці. Досліджено організацію внутрішнього контролю на всіх етапах відтворювального процесу виробництва продукції підприємств харчової промисловості.

Ключові слова: ефективність праці, контроль, внутрішній контроль, управління, стимулювання, мотиваційний механізм, етапи контролю.

This work is licensed under a Creative Commons Attribution 4.0 International License http://creativecommons.org/licenses/by/4.0/

Постановка проблеми та їі зв'язок з важливими науковими та практичними завданнями. Сучасна ринкова економіка України в умовах глобалізації, для спроможності конкурувати на світовому ринку, передбачає високу ефективність праці. Основою такої праці є інноваційний підхід, впровадження результатів дослідження НТП у виробництво. Ефективність праці, як елемент (підсистема) в системі ефективності виробництва, займає головну позицію в напрямках підвищення ефективності виробництва.

Поняття «ефективність» в економічній літературі розглядається як співвідношення результатів корисного ефекту і витрат, що пов'язані з отриманням даного результату. На ефективність впливає низька моментів: планування і стимулювання трудової діяльності, організація праці і виробництва, система управління підприємством. При цьому, ефективність праці повинна розглядатись на різних організаційноекономічних рівнях: макроекономіки (держава, регіон, галузь) i безпосередньо на підприємстві, його структурних підрозділах, ланках і окремого робітника.

Таким чином, ефективність праці, є однією 3 актуальних проблем держави, регіонів, підприємства та кожного робітника, тому як від неї залежить потенціал їх економіки, а також добробут кожної людини суспільства. Тобто ефективність праці багатогранна категорія, яка вирішує питання не тільки економічні, але й соціальні, які можуть бути виражені в якості наданих послуг та виробленої продукції, ступені задоволення потреб населення, тощо.

Питання ефективності праці взагалі цікавило економістів, починаючи із зародження держави до сучасного часу, ними займались різні наукові школи.

В першу чергу, це питання співвідношення необхідного та додаткового продукту, необхідної та додаткової праці, необхідного робочого часу і додаткового робочого часу, роль живої і уречевленої праці в процесі створення продукту, послуги, ступень експлуатації найманої праці та вартості робочої сили та інше.

Аналіз останніх публікацій по проблемі. Узагальнення теоретичних питань і розробка методології підвищення ефективності виробництва і праці досліджувались такими іноземними і українськими вченими, як Л.І.Абалкін, Л.М.Гатовський, Д.Н.Карпухін, Є.І.Капустін, О.А.Турецький, Н.Г.Чумаченко, С.І Шкурко та ін.

Окремі аспекти дослідження ефективності праці отримали розвиток в роботах В.Ф.Андрієнка, Д.П.Богіні, Л.Є.Кунельского, І..Я. Обломської. Питання взаємозв'язку ефективності праці з продуктивністю праці, з рівнем іiі оплати та прибутковістю відображені в працях О.С.Богачевої, А.М.Вознюка, В.І.Осипова, О.П.Ощепкова, А.Ревенко та ін.

Формулювання цілей дослідження. Метою дослідження $є$ ефективність використання праці та організація контролю за прийняттям рішень 3 підвищення iï ефективності.

Виклад основних результатів та їх обгрунтування. Динаміка сучасного виробництва, особливо в розвинутих країнах, характеризується зміною розподілу праці, розширенням обсягів трудових задач та функцій, які не піддаються безпосередньому контролю та вартісній оцінці. Суб'єкт праці становиться невід'ємним учасником успіху або фіаско підприємства, співучасником високої якості виробництва, його безпеки, підприємницької активності [1, с.112].

Результативність праці, як одна із складових ефективності праці, залежить від того, наскільки ор- 
ганізація праці і весь стимулюючий механізм зацікавлює робітника в кінцевому результаті діяльності підприємства. Тобто, наскільки економічні інтереси окремого робітника і економічні інтереси підприємства узгоджені і відповідають місії підприємства щодо задоволення суспільних потреб.

Іншою складовою $є$ продуктивність праці, яка повинна розкриватися через рівень техніки, що використовується, рівень організації виробництва, праці та технології, а також рівень кваліфікації робітників.

Таким чином, ефективність праці розглядається як реалізація мети підприємства, створення споживчих вартостей, які задовольняють суспільні потреби населення або інших виробників. При цьому, коли створені продукти не задовольняють потреби суспільства, витрати праці вважаються неефективними і нераціональними, тому що не відповідають меті виробництва.

Для харчової промисловості нераціональні або неефективні витрати притаманні в зв'язку з обмеженими строками реалізації окремих видів продукції, після чого вона вважається не придатної до споживання повністю або частково. Остання використовується для подальшої переробки (наприклад, хліб). Таким чином, для підприємства важливо ув'язувати результати праці з оцінкою кінцевого корисного ефекту від споживання виробленої продукції або наданої послуги.

Для того, щоб мета підприємства була реалізована, необхідно створити механізм контролю ефективності праці, який повинен здійснюватись на кожному етапі або циклі відтворювального процесу використання праці і руху продукту, починаючи з прийняття рішення про виготовлення продукту, виконання прийнятого рішення і контролю результатів виконання цього рішення.

Що стосується методології оцінки ефективності праці в умовах становлення сучасного ринкового господарства залишаються не вирішеними низка питань: треба враховувати фактори конкуренції, розбалансованість ресурсів, загальний низький рівень оплати праці, обмеження купівельної спроможності населення - все це потребує нових підходів до оцінки ефективності праці, нових форм, видів і методів стимулювання ефективної праці на рівні підприємства, структурних підрозділів і окремого робітника.

Ефективність праці як форма ступеню реалізації економічних і соціальних цілей праці, залежить від побудови механізмів організації виробництва i праці з урахуванням мотиваційного механізму. На це звертає увагу в своєї роботі А.Г. Гончарук: «організаційно-економічний механізм ефективності виробництва повинен включати мотиваційний механізм для якісного виконання приймаючих рішень» $[2$, с.205206]. Цей мотиваційний механізм повинен включати обов'язково відповідальність за прийняття відповідних рішень і за виконання прийнятих рішень кожним структурним підрозділом і окремим робітником.

Побудова такого стимулюючого механізму буде залежить від організаційно-економічного рівня підприємства, форми власності і господарювання. В залежності від цього буде формуватися система контролю за прийняттям рішень, виконанням цих рішень i безпосередньо за результатами виконання прийнятих рішень, а також структура і механізм контролю. Особливе значення в сучасних ринкових умовах має визначення ступеню ризику в процесі приймання того чи іншого рішення, спрямованого на підвищення ефективності праці. Як раз відповідальність за прийняття рішення повинна враховувати зовнішні і внутрішні загрози невиконання цих рішень.

Також треба здійснювати постійний моніторинг, на скільки вироблений продукт характеризує ступінь задоволення споживчих потреб. Це пов'язано 3 тим, що у споживачів можуть змінюватись пріоритети в споживанні, які обумовлені структурою населення, рівнем його доходів та структурою розподілу доходу населення, тобто яка саме його частина спрямована на власне споживання, та наявністю конкурентної боротьби на споживчому ринку.

Для досягнення цього завдання необхідна організація внутрішнього контролю за ефективністю праці. Контрольні функції за ефективністю праці покладаються практично на всі ланки управління: від робочого місця робітника до керівника підприємства. Інформаційне забезпечення буде здійснюватись за допомогою оперативного, статистичного і бухгалтерського обліку. Система контролю повинна бути побудована таким чином, щоб рух продукції, що виробляється, контролювався від постачання сировини до кінцевого споживання.

Поняттю «контроль», його сутності присвячено багато досліджень, але єдності поглядів на дане поняття не має. Одні автори розглядають його як систему поглядів і перевірки відхилень від заданих параметрів (Бутинець Ф.Ф., Афанасьєв В.Г., Петренко В.В. та ін..), інші відносять контроль до характеристик виявлення невідповідальності заданим нормативам, параметрам, підзаконним актам (Лозовський Л.Ш., Шевчук В.К., Усач Б.Ф. та ін.). Огляд різних підходів до понять контролю наведено авторами Л.М. Сухаревою та С.Н.Петренко [3, с.6-8]

Контроль $є$ умовою ефективного управління підприємством і виступає елементом системи управління. Як відмічає Павлюк В.В., «контроль, являясь, элементом управления, представляет собой сложный процесс, направленный на проверку соответствия контролируемых объектов предъявлемым к ним требованиям и заданным параметрам» [4, с.5 ].

На контроль, як процес, вказують і автори посібника «Основи менеджмента»: «контроль - это процесс обеспечения достижения организацией своих целей. Процесс контроля состоит из установки стандартов, измерения фактически достигнутых результатов и проведения корректировок в том случае, если достигнутые результаты существенно отличаются от установленных стандартов» [5, с.390].

Ми не можемо погодитися 3 тими вченими, які розглядають контроль, як сукупність методів, способів, заходів виявлення недоліків та спрямованих на їх усунення. На нашу думку, зазначене є лише ін- 
струментами, за допомогою яких здійснюється контроль, а не є саме його сутністю [6].

Нами розглядається контроль як процес, який включає контроль прийняття рішень, контроль виконання прийнятих рішень та контроль результатів виконання прийнятих рішень.

3 точки зору мети та організації контролю, його поділяють на економічний контроль, державний контроль, фінансовий контроль, господарський контроль, фінансово-господарський контроль, внутрішньо-господарський контроль [ 3, с.18-24].

Організацію контролю ефективності праці, як складової ефективності виробництва, ми можемо віднести до господарського контролю, тому що до нього відносяться питання внутрішнього контролю та фінансово-господарського контролю. Найбільш повну характеристику господарського контролю дав колектив авторів під керівництвом Ф.Ф Бутинця: «Хозяйственный контроль - это процесс наблюдения и проверки производственной и финансовой деятельности, предприятий....с целью выявления отклонений от установленных параметров этой деятельности, устранение и предупреждение отрицательных явлений и тенденций» [7, с.12].

Контроль будь-яких ресурсів складається 3 трьох етапів: попередній, поточний і кінцевий (заключний). Це відноситься і до людського ресурсу. На попередньому етапі контролю здійснюється ретельний аналіз тих ділових і професійних знань і навичок, які необхідні для виконання певних посадових обов'язків, вміння виконувати роботу відповідної складності. Але в сучасних умовах цього не достатньо, треба, щоб людина мала вміння працювати в команді на кінцевий результат. Для цього необхідно проводити анкетування з метою складання соціального портрету майбутнього робітника, який може бути підставою для побудови мотиваційного механізму для конкретного працівника, або групи працівників, які виконують однакову роботу.

Поточний контроль ефективності праці характеризує, яким чином застосовуються безпосередньо знання і вміння робітника в процесі реалізації прийнятого рішення при досягненні мети підприємства. Тобто, як використовуються ресурси та робочий час, забезпечується ритмічність роботи, виконуються вимоги технологічного процесу виробництва і реалізації продукції. Одночасно здійснюється контроль за можливими відхиленнями та їх коригування 3 метою досягнення кінцевої мети діяльності підприємства. На цьому етапі інформаційне забезпечення здійснюється шляхом методів статистичного спостереження, оперативного та статистичного контролю.

На заключному етапі контролю здійснюється аналіз результатів виконання прийнятих рішень, які спрямовані на досягнення стратегічної мети діяльності підприємства та його структурних підрозділів. Інформаційне забезпечення здійснюється за допомогою статистичного, бухгалтерського фінансового та податкового обліку. За результатами заключного контролю ми отримаємо інформацію, яка необхідна для подальшого планування діяльності, а також робляться певні висновки: щодо відповідності мотиваційного механізму меті, ефективності здійснення розподілу доходу підприємства, визначається на скільки він погоджує і реалізує інтереси підприємства, структурних підрозділів і окремого робітника. Тобто, відповідно теорії очікування, існує чітка залежність між результативністю праці та іiі винагородою. На підставі результатів заключного контролю може бути скоригована тактична мета діяльності підприємства.

Особливим $\epsilon$ те, що результати заключного контролю повинні бути доведені до кожного робітника - як досягнення, так і недоліки кожної структурної ланки і окремого робітника. Тобто, оцінюється робота команди.

Важливим кроком при вимірюванні ефективності праці являється відповідний вибір системи показників, за допомогою яких буде визначатись ця ефективність. Основними вимогами до системи показників ефективності праці $є$ :

- відображення кінцевих результатів діяльності;

- підвищення якості продукції та іiі споживчих властивостей;

- порівняння і зведеність показників по рівнях системи управління;

- співвідношення натуральних, трудових і вартісних показників.

Розрахунок результативності цих показників повинен відображати абсолютну і відносну величини економічної і соціальної ефективності праці. 3 точки зору результативності і отримання прибутку, вироблена продукція ще не гарантує його отримання, тому що вона може бути не реалізована. Тому, для оцінки результативності рекомендуємо використовувати чистий дохід для підприємств харчової промисловості.

В процесі аналізу і контролю ефективності праці виявляються резерви подальшого підвищення ефективності праці, які класифікуються за різними рівнями і напрямками, за багатьма ознаками, охоплюють різні аспекти їх формування і реалізації. Більше уваги до контролю потребують резерви внутрішнього характеру, які пов'язані з удосконаленням i ефективним використанням техніки і технологій, машин, обладнання, раціональною організацією виробництва і праці, якісним складом працівників, ефективним використанням робочого часу, удосконаленням мотиваційного механізму, який включає заохочення i санкції та дає можливість реалізації власних здібностей робітника.

В сучасних ринкових умовах, при переході до інноваційного типу розвитку економіки, значно зростає роль минулої праці для досягнення більшої ефективності живої праці. Це пов'язано зі ступенем ресурсозабезпеченості, зростанням енергоозброєності праці та питомої ваги матеріально-технічної бази. В зв'язку з цим, для впровадження інноваційного типу праці, нами пропонується частину прибутку, яка отримана за рахунок зростання продуктивності праці не оподатковувати та залишати на підприємстві для цільового використання на інноваційні процеси. 
Висновки та перспективи подальших досліджень. В результаті проведеного нами дослідження було визначено, що ефективність праці розкриває економічні і соціальні аспекти розвитку підприємства, відображає результати діяльності різних рівнів від робітника до підприємства в цілому.

Ефективність праці була розглянута через призму категорій продуктивності праці та його результативності, на скільки задовольняються потреби споживачів та отримання прибутку від реалізації про- дукції.

Запропоновано для підвищення ефективності праці проводити внутрішній контроль на всіх етапах відтворювального процесу виробництва.

Для підвищення дії мотиваційного механізму щодо впровадження інноваційних процесів на підприємствах, запропоновано залишати частину неоподаткованого прибутку, який отримано за рахунок зростання продуктивності праці, на підприємстві для цільового використання на інновації.

\title{
Література
}

1. Мухаметлатыпов Р.Ф. Труд и капитал: концептуальная модель, проблемы развития и управления / Р.Ф. Мухаметлатыпов, Ф.У. Мухаметлатыпов. - Уфа: Уфимская государственная академия экономики и сервиca, 2012. $-340 \mathrm{c}$.

2. Гончарук А.Г. Управление эффективностью деятельности предприятия / А.Г. Гончарук. - Одесса: Астропринт, 2012. - 260 с.

3. Сухарева Л.А. Контроль и ревизия: практикум: [учеб. пособие] / Л.А. Сухарева, С.Н. Петренко. - К.: Ника-Центр, Эльга, 2003. - 202 с.

4. Павлюк В.В. Контроль и ревизия: [учеб. пособие] / В.В. Павлюк. - Донецк: Кассиопея, 2000. - 135 с.

5. Мескон М.Х. Основы менеджмента: пер. с англ. / М.Х. Мескон, М.Альберт, Ф.Хедоури. - М.: Дело, 1992. $-702 \mathrm{c}$.

6. Медвідь Л.Г. Організаційно-методичні аспекти внутрішнього контролю діяльності торговельних підприємств у конкурентному середовищі [Електронний ресурс] / Л.Г.Медвідь, Л.О.Хариновія - Яворська // Електронне наукове фахове видання «Ефективна економіка». - 2014. - №11. - Режим доступу : http//www.economy.nauka.com.ua/?op=1\&z=3524

7. Контроль и ревизия / [Ф.Ф. Бутынец, С.В.Бардаш, Н.М.Малюга, Н.И. Петренко]. - Житомир: ЖИТИ, 2000. $-512 \mathrm{c}$.

8. Шедяков В.В. Трансформації відчуження праці в контексті розвитку виробничої демократії / В.В.Шедяков // Формування ринкових відносин в Україні. - 2014. - №10. - С. 152 - 157

9. Егоршин А. П. Мотивация трудовой деятельности: [учеб. пособие] / А.П. Егоршин. - Н.Новгород: НИМБ, 2007. - 320 с.

10. Сербиновский Б. Ю. Мотивация и эффективность труда [Електронний ресурс] / Б.Ю.Сербиновский. - Режим доступу : http//www.psyera.ru/4816/ motivacija-i-effektivnost-truda

11. Кузнецова Н. Б. Оценка трудового вклада и эффективности труда работников / Н.Б. Кузнецова, А.Ш. Галимова // Молодой ученый. - 2013. - №1. - С. 136-138.

\author{
Магденко С.A. \\ ассистент \\ кафедра экономики промышленности \\ Одесская национальная академия пищевых технологий \\ ул. Канатная, 112, г. Одесса, Украина, 65039 \\ E-mail: maglana@meta.ua
}

\section{ВНУТРЕННИЙ КОНТРОЛЬ ЭФФЕКТИВНОСТИ ТРУДА НА ПРЕДПРИЯТИЯХ ПИЩЕВОЙ ПРОМЫШЛЕННОСТИ}

Эффрективность труда, как элемент (подсистема) в системе эффективности производства, занимает главенствующую позицию в направлениях по ее повышению, должна рассматриваться на 
различных организационно-экономических уровнях: на предприятии в целом, в его структурных подразделениях, участках и каждого работника отдельно.

Эффрективность труда - многогранная категория, которая направлена на решение вопросов не только экономического, но и социального характера, рассматривается как реализация цели предприятия, создание потребительных стоимостей, которые удовлетворяют общественные потребности населения или других потребителей.

В качестве составляющих эффективности труда рассматриваются его производительность и результативность.

Для реализации цели предприятия необходимо создать механизм контроля эффективности труда, который должен осуществляться на каждом этапе или цикле воспроизводственного процесса использования труда и движения продукта, начиная с принятия решения о производстве продукта, выполнения принятого решения и контроля результатов выполнения этого решения.

Внутренний контроль каких-либо ресурсов, в том числе и человеческих, состоит из трех этапов: предварительный, текущий и конечный (заключительный). На предварительном этапе контроля осуществляется тщательный анализ тех деловых и профессиональных знаний и навыков, которые необходимы для выполнения определенных должностных обязанностей, умение выполнять работу соответствующей сложности и построения мотивационного механизма для конкретного работника или группы работников, выполняющих одинаковую работу.

Текущий контроль эффективности труда характеризует, каким образом применяются непосредственно знания и умения рабочего в процессе реализации принятого решения при достижении цели предприятия.

На заключительном этапе контроля осуществляется анализ результатов выполнения принятых решений, направленных на достижение стратегической цели деятельности предприятия и его структурных подразделений.

В результате проведения внутреннего контроля эффективности труда выявляются резервы возможного дальнейшего ее повышения, организовывать которую необходимо на инновационной основе.

Ключевые слова: эффрективность труда, контроль, внутренний контроль, управление, стимулирование, мотивационный механизм, этапы контроля.

\author{
Magdenko S. \\ Assistant \\ Department of Industrial Economics \\ Odessa National Academy of Food Technologies \\ Kanatna str., 112, Odessa, Ukraine, 65039 \\ E-mail:maglana@meta.ua
}

\title{
THE INTERNAL CONTROL OF EFFICIENCY OF LABOR IN THE FOOD INDUSTRY
}

The efficiency of labor, as an element (subsystem) in the system of production efficiency, occupies a dominant position in its areas of improvement should be considered in various organizational and economic levels: the enterprise as a whole, its structural divisions, sections, and the individual worker.

The effectiveness of labor - a multi-faceted category, which is aimed at addressing not only the economic, but also social issues, is seen as the realization of the goal of the enterprise, creation of use-values which satisfy the social needs of the population or from other consumers.

As part of the efficiency of labor considers its performance and effectiveness.

To implement the objectives of the enterprise must create a mechanism to monitor the efficiency of labor, which should be carried out at each stage of the cycle or the reproduction process of using labor and product movement, starting with the decision to manufacture the product, the implementation of the decision of the control and implementation of that decision.

Monitoring any resources, including human, consists of three stages: preliminary, current and final. 
At the preliminary stage, the control is carried out a thorough analysis of the business and professional knowledge and skills that are required to perform certain duties, the ability to do the job and the corresponding difficulty of constructing a motivational mechanism for a particular employee or group of employees performing the same work.

Monitoring the efficiency of labor characterizes the way in which directly applied the knowledge and skills of workers in the process of implementation of the decision when the enterprise goals.

The final stage of control is carried out analysis of the implementation of decisions aimed at achieving the strategic goals of the company and its business units.

As a result of the effectiveness of internal control labor reserves identified possible further to improve it, to be organized on the basis of innovation.

Keywords: labor efficiency, control, management, promotion, motivational mechanism, control steps.

\section{References}

1 Mukhametlatupov, R. F. (2012). Trud y kapytal: Kontseptualnaia model, problemu razvytyia y upravlenyia. Ufa, Russia: Ufymskaia hosudarstvennaia akademyia ekonomyky y servysa.

2. Honcharuk, A. H. (2012). Upravlenye effektyvnostiu deiatelnosty predpryiatyia. Odessa: Astroprynt.

3. Sukhareva, L. A., \& Petrenko, S. N. (2003). Kontrol y revyzyia: Praktykum. K.: Nyka-Tsentr.

4. Pavliuk, V. V. (2000). Kontrol y revyzyia. Donetsk: Kassyopeia.

5. Meskon, M. K., Albert, M., \& Khedoury, F. (1992). Osnovu menedzhmenta. M.: Delo.

6 Medvid, L. H., \& Kharynoviia - Yavorska, L. O. (2014, November). Orhanizatsiino-metodychni aspekty vnutrishnoho kontroliu diialnosti torhovelnykh pidpryiemstv u konkurentnomu seredovyshchi. Retrieved from http//www.economy.nauka.com.ua/?op=1\&z=3524 ZhYTY.

7. Butunets, F. F., Bardash, S. V., Maliuha, N. M., \& Petrenko, N. Y. (2000). Kontrol y revyzyia. Zhytomyr:

8. Shediakov, V. V. (2014). Transformatsii vidchuzhennia pratsi v konteksti rozvytku vyrobnychoi demokratii. Formuvannia Rynkovykh Vidnosyn v Ukraini, 10, 152-157.

9. Ehorshyn, A. P. (2007). Motyvatsyia trudovoi deiatelnosty. N.Novhorod: NYMB.

10. Serbynovskyi, B. I. Motyvatsyia y effektyvnost truda. Retrieved from http//www.psyera.ru/4816/ motivacija-i-effektivnost-truda

11. Kuznetsova, N. B., \& Halymova, A. S. (2013). Otsenka trudovoho vklada y effektyvnosty truda rabotnykov. Molodoi Uchenui, 1, 136-138.

Received 12 February 2016

Approved 26 February 2016

Available in Internet 29.03.2016 